\title{
Processions and Architecture of Papal Rome in Relation to the Stay of the Salonica Brothers in Rome
}

\author{
Martin Husár
}

\begin{abstract}
The character of Constantine and Methodius' presence in Rome was also determined by the policy, ideology and ceremonial system of the Holy See. There are several primary literary sources mainly written in Latin and Slavonic that concern the aforementioned statement. In a way the liturgy of Easter Week or the other stational liturgies in early medieval Rome might have influenced a celebration of the Slavonic liturgy in $867 / 868$. The presentation of the Slavonic liturgy lasted for three days and took place within the Aurelian walls as well as the parts of Rome situated behind this main fortification of the city. The Popes apparently gave audiences to the so called Salonica brothers (Constantine and Methodius) in the most significant sites of the Vatican complex, Lateran palace or in some great churches like the Basilica of St. Mary Major. The aulae, triclinia, atria, and secretaria primarily belonged to the aforementioned sites where the Pope mainly received visitors, officers, proclaimed synod resolutions and addressed the Romans.
\end{abstract}

\section{Keywords}

Constantine-Cyril; Methodius; the Papal court; Rome; ceremonies; the Early Middle Ages

\footnotetext{
This work was supported by the Slovak Research and Development Agency under Grant number APVV-160116 and by the Scientific Grant Agency of the Ministry of Education, Science, Research and Sport of the Slovak Republic and the Slovak Academy of Sciences under Grant number 1/0468/15. The author of the article thanks John F. Romano for notes and suggestions on the early medieval liturgy in Rome.
} 


\section{Evidence of the Direct Primary Sources}

The author of this article has focused on the processional and architectonical aspects of Constantine and Methodius' stays in Rome which have, as yet, not been treated in the following manner. ${ }^{1}$

Sts. Cyril and Methodius, present-day co-patron saints of Europe, were important diplomats and missionaries ${ }^{2}$ of the Byzantine Empire and missionaries of Great Moravia. They visited Rome, where they presented and defended the Slavonic liturgy ${ }^{3}$ before Popes Hadrian II and John VIII. Both of them are supposed to have had audiences, ceremonies or court rituals organised by the Papal court. We have direct and indirect information regarding this from several primary sources - as Ordo Romanus Primus, Vita Constantini-Cyrilli cum translatione s. Clementis, ${ }^{4}$ Vita Hadriani II., ${ }^{5}$ Žitije Konstan-

1 For instance, the historical and political background of the presence of Constanine and Methodius in Rome during the pontificate of Hadrian II (867-872) and John VIII (872-882) was excellently examined by František Dvorník (1970), Richard Marsina (1985) and Vladimír Vavřínek (2013). A lot of contemporary and later scholars drew upon their legacy. The same background of the Salonica brothers' stay in Rome in 867-869 was presented by Anthony-Emil N. Tachiaos (2002: pp. 210-221). Josef Cibulka (1964: pp. 15-17) briefly dealt with the history of churches in Rome where the Slavonic liturgy was celebrated in 867/868. Šimon Marinčák (2005: pp. 34-62) and Andrej Škoviera (2007: pp. 104-130) investigated the matter of Slavonic liturgy, inter alia, in relation to the visit of Constantine and Methodius in Rome. Interactions between the Holy See and the Salonica brothers were observed by Maddalena Betti (2014). The matter of the most possible route of Constantine and Methodius' journey to Rome was tackled by Josef Cibulka (1965: pp. 326, 346-363) and this was recently reassessed by Peter Ivanič and Martina Lukáčová again (2014a: pp. 98-103; 2014b: pp. 9-11; 2015: pp. 655-658).

2 At least at the beginning of their missionary activity they drew on the Byzantine rite of the Christian East. In Constantine and Methodius' homeland the Church practised two forms of the Byzantine rite and (more or less) their synthesis in the 9th century. It was the monastic form, the cathedral/parish form

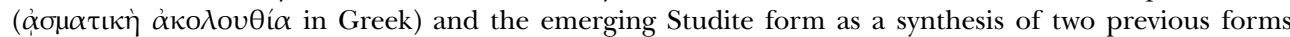
(Marinčák 2005: p. 46; Škoviera 2007: pp. 104-109, 120-122; Taft 1992: pp. 56, 58, 60).

3 Initially, the Slavonic liturgical language was most likely approved by the permanent patriarchal synod of Constantinople and Emperor Michael III (842-867) in 862 or 863. It is obvious that the Eastern Church supported many liturgical languages and the Slavonic language could not have been an exception (Škoviera 2013b: pp. 13-14, 16, 27). By contrast, official affirmation of another liturgical language in Rome was something unusual and extraordinary. The Western Church and the Holy See perceived only Hebrew, Greek and (first and foremost) Latin as canonical languages. Nonetheless, Abbot Strabo of Aachen wrote in his book dated between 840 and 842 on liturgical history (Libellus) that there was variety in the liturgy, not only by race or language, but also within one race or language (Doig 2009: pp. 146-147). Popes Hadrian II (868) and John VIII (880) temporarily accepted the Slavonic liturgical language (Pentkovskij 2014: p. 102). However in Rome the Slavonic liturgy was probably celebrated in compliance with the Roman/Latin form of the Western rite, then in the territory the Middle Danube region it could also have been celebrated in other forms of the Western rite (probably the Salzburg or Aquileian form) or even in the Byzantine rite. But it remains an unsettled issue (Škoviera 2007: pp. 112-119, 129; Škoviera 2013b: pp. 15, 22-23).

4 The so called Italian or Roman legend was preserved by its two manuscripts. The first one was discovered in the Vatican and although it dates back to the 12th century, it might have formerly been composed by Bishop Gauderich (of Velletri), a contemporary of Constantine and Methodius. The second manuscript, which includes a prologue that is not a part of the Vatican manuscript, was already rewritten or copied by Leo of Ostia (before 1050-1115; Geary 2011: p. 44) and finally preserved in the codex N XXIII from Prague dating back to the 14th century (Bartoňková \& Večerka 2010: pp. 102, 103). For the purpose of this article I use the critical version of the aforementioned legend which is based on the latter manuscript 
tina Filosofa ${ }^{6}$ (The Life of Constantine the Philosopher), Žitije Mefodija, archijepiskopa

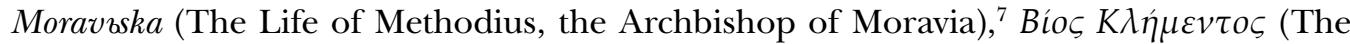
Long Life of St. Clement of Ohrid), ${ }^{8}$ and by the bull of Pope John VIII called Industriae tuae. ${ }^{9}$ In these primary sources I was able to find the following accounts concerning Constantine-Cyril and Methodius at the Papal court and in the territory of Rome.

According to the so called Italian or Roman legend, when Pontiff Hadrian II at the arrival of Constantine and Methodius in $\operatorname{Rome}^{10}(867 / 868)^{11}$ " ... got to know that the aforementioned Philosopher was carrying the body of St. Clement ${ }^{12} \ldots$, he much rejoiced that and stepped out with the clergy and people of the city to meet them, then he received them with great honours." (V. Con.-Cyr. 9: p. 110). This occasion is also mentioned in other primary sources (Žit. Kon. XVII: p. 90; Poch. Slovo: p. 148; B. Klim. III, 9: p. 182; Usp. Kir.: p. 224; Leg. sanct. 6: p. 236). ${ }^{13}$

Another occasion, that gave new momentum to the Cyrillo-Methodian mission, is the consecration of the Slavonic liturgical books at the Basilica of St. Mary Major ${ }^{14}$ as well as

(V. Con.-Cyr.: pp. 103-113) firstly published by Paul Devos and Paul Meyvaert (Devos \& Meyvaert 1955: pp. 455-461), apart from two passages.

5 The biography is unfinished and incomplete (the main text does not surpass December 870) and it has an unknown author (Davis 1995: p. 249). Hadrian II's life is a biography within the Liber Pontificalis. Apart from the previous biographies, this one belongs to those which were compiled by contemporary writers from the first half of the seventh century to the late ninth century (Davis 1995: pp. x-xi). Nonetheless, the probable original edition of the Liber Pontificalis had to be reconstructed from various medieval manuscripts.

6 The first version of Constantine's life might formerly come from the Great Moravian literary school and we can also consider Methodius to be its author. The oldest preserved manuscripts cannot be dated before the 15th century. In this article I rely on the manuscript from the first half of the 15th century which was designated as no. 1 by Pyotr Alekseyevich Lavrov (Bartoňková \& Večerka 2010: pp. 38, 42).

7 The Life of Methodius originates in Great Moravia and it was composed soon after Methodius' death, i.e. between 885 and the beginning of 886 . The oldest manuscript from the preserved ones, whose critical edition is used in this article, dates back to the 12th century and it originates from the proceedings of the Uspenski cathedral in Moscow (Bartoňková \& Večerka 2010: pp. 114, 116).

8 The so called Bulgarian legend was written by Theophylact of Ohrid (the Bishop of Ohrid) at the end of the 11th century and beginning of the 12th century (Delikari 2015: p. 8; Obolensky 1988: pp. 11-12; Škoviera 2013a: p. 144). Nevertheless, it is claimed that this life story could be based on the previous unknown Slavonic biographies that were compiled by one or more followers of Clement of Ohrid, shortly after his death (Delikari 2015: p. 8).

9 The bull is dated to June 880 (Bartoňková \& Večerka 2011: p. 161).

10 Initially they presumably did not plan to come to Rome on their own initiative and they might have intended to set sail for Byzantium from Venice where they received an invitation (in the matter of their disputes with the Latin clergy over the Slavonic liturgy in Venice) from Pontiff Nicholas I (858-867) in late autumn 867 (Dvornik 1970: pp. 131-133; Löwe 1983: pp. 655-656).

11 Constantine and Methodius arrived in Rome in December 867 or at the beginning of the year 868 at the latest, because Nicholas I, who invited them to Rome, died on the 11th of November 867 and the new Pope, Hadrian II, took office on the 14th of December 867 (Dvornik 1970: p. 131).

12 He was the fourth Pope (92-101) who died in Kherson as a martyr (Cibulka 1965: pp. 325, 362-363).

13 Even crosses, candles, torches, and incense burners are mentioned in the hands of the welcomers (Žit. Kon. XVII: p. 90; B. Klim. III, 9: p. 182; Usp. Kir.: p. 224).

14 "Then the Pope (Hadrian II) accepted the Slavonic books. The Pope blessed and placed them in the church of St. Mary that is called Fatné (Basilica Sanctae Mariae Maioris in Latin, Basilica di Santa Maria 
the ordination of Methodius and his disciples at the Basilica of St. Peter ${ }^{15}$ (Betti 2014: pp. 67, 103-104; Löwe 1983: p. 657). On the altar of the last mentioned basilica the Pontiff laid the Slavonic evangeliary (Žit. Mef. VI: p. 126). In the ensuing two days ${ }^{16}$ the liturgy was also chanted at the Chapels of St. Petronilla and St. Andrew and at the Basilica of St. Paul outside the Walls. ${ }^{17}$ There is no doubt (and I will discuss this later) that all of the three aforementioned basilicas were ancient churches usually used during the stational liturgy of Easter Week and other stational liturgies in Rome (Baldovin 1987: p. 156; Dey 2011: pp. 227-228; Romano 2007b: fig. 4.3; Romano 2009: p. 348) even before the $9^{\text {th }}$ century. According to primary literary sources the Slavonic liturgy was chanted at the Basilica of St. Peter and St. Paul outside the Walls (Marinčák 2005: p. 40).

After Cyril's death (the $14^{\text {th }}$ of February 869; Grotz 1970: pp. 172, 174; Žit. Kon. XVIII: p. 93) “... his (Cyril's) aforementioned brother, Methodius, came to the saint high priest himself (Hadrian II) and having got down before him, to his (Pope's) legs, he (Methodius) said:..." (request to hand Cyril's body over; V. Con.-Cyr. 11: pp. 111-112). Cyril was then placed in a marble coffin, which was sealed by Hadrian II's own seal, and buried in the Church of St. Clement after all (Grotz 1970: p. 175; V. Con.-Cyr. 12: pp. 112-113). His tomb was prepared on the right side of the altar and at his funeral “... a large number of clergymen and people was gathered ... giving thanks to God together with hymns and chants, ..." (V. Con.-Cyr. 12: pp. 112-113).

In regard to the Life of Methodius, the Archbishop of Moravia, Methodius alone was later (later in the year 869; Betti 2014: p. 43, footnote 3; Obolensky 1988: p. 17) received by the Prince of Lower Pannonia, Kocel (861-876), “... with great honour and he was sent to the Pope again - as well as twenty men, men of noble origins, in order to consecrate

Maggiore in Italian). Later on the liturgy was chanted over them.” (Žit. Kon. XVII: p. 90). It is likely that these books were carried to the altar here. This assertion is based on the account of the Long Life of St. Clement of Ohrid (B. Klim. III, 9: pp. 182-183).

15 "And after that the Pope appointed two bishops, Formosus and Gauderich, so as to ordain the Slavonic disciples. As soon as they were ordained, they chanted the liturgy in Slavonic language at the Church of St. Peter.” (Žit. Kon. XVII: pp. 90-91). "Then he (the Pope) ordained beatific Methodius as a priest.” (Žit. Mef. VI: p. 126). Andrej Škoviera stressed that the ordination of Methodius and Constantine's disciples should have surely been carried out in the Roman rite (Škoviera 2007: p. 118). Among their disciples in Rome Clement of Ohrid and Naum of Ohrid should have been present according to the 16th century Second Slavonic Life of St. Naum of Ohrid (Žit. Nau. II: p. 227).

16 As I have already stated, on the first day the Slavonic books were blessed in the Basilica of St. Mary Major and the Slavonic liturgy was presented in the Basilica of St. Peter (Žit. Kon. XVII: pp. 90-91).

17 "And on the second day they chanted at the Church of St. Petronilla, and on the third day they chanted at the Church of St. Andrew and then they even chanted the liturgy in the Slavonic language in the church of the great teacher of nations, St. Paul - the Apostle, at night, over the grave of the saint. Bishop Arsenius, one of the seven bishops, and Anastasius the Librarian, helped them.” (Žit. Kon. XVII: p. 91). These events should be dated before the 10th of March 868 because the son of Bishop Arsenius, Eleutherius, kidnapped Pope Hadrian II's daughter and wife on this date and subsequently Arsenius was accused of having helped his son. Then Arsenius decided to flee Rome and move to Southern Italy where he would have found shelter at the court of Emperor Lothar II (855-869; Dvornik 1970: p. 139). It is not clear what kind of a rite (Western or Byzantine), during the aforementioned celebration at St. Paul outside the Walls, was used. At least Bishop Arsenius could barely speak the Slavonic language and therefore it would have been a problem for him to preside over that Mass (Škoviera 2007: p. 118). 
him (Methodius) for the episcopal office in Pannonia, ... That also happened." (Žit. Mef. VIII: p. 130).

Once again Methodius appeared before the Pope, now John VIII, sometime between 879 and 880 (Betti 2014: p. 87), or not until 880 (Löwe 1983: p. 680; Marsina 2012: pp. $92,98)$. He came to Rome to defend the use of the Slavonic liturgy and orthodoxy of his creed (Marsina 2012: pp. 80-81, 92). John VIII finally approved his orthodoxy and the Slavonic liturgy ${ }^{18}$ against the doubts of the Moravian Prince Svätopluk (871-894) and the Bavarian clergy in 880 (I. tuae: pp. 161 173; Betti 2014: p. 87).

The aforementioned primary sources should be put into context by the next remarks and indirect clues with intent to find out the information about processional and architectural aspects of Constantine-Cyril and Methodius' stay at the Papal court and in Rome.

\section{II.1 On processions}

Constantine and Methodius' arrival in Rome with the mortal remains of St. Clement in 867, their presence in Rome between 867 and 869, and arrivals of Methodius there in 869 and 879/880 relate to the time of the Papal republic ${ }^{19}$ when the Roman Popes were beginning to be more intensively interested in the lives of their predecessors themselves and a history of the Church, so that they could improve their authority.

Transportation of mortal remains of Christian martyrs and saints from the unprotected outskirts of Rome ${ }^{20}$ or from abroad to Roman churches and the Lateran palace had already begun on behalf of two pontiffs of Eastern origins in the $640 \mathrm{~s} .{ }^{21}$ Relocation of martyrs' bones was more or less the custom of the Church in the East. This custom had been refused by the Popes before (Krautheimer 2000: pp. 90, 113). Moreover there was the cannon of the Council of Carthage (401) that all altars, where mortal remains of ordinaries or martyrs were not present, should be demolished (Doig 2009: p. 89). Relics were transported in large scale to the churches and monasteries within the walls of Rome since the second half of the $8^{\text {th }}$ century, concretely since the pontificate of Paul I (757-767; Collins 2009: p. 156; Costambeys \& Leyser 2007: p. 274; Dey 2011: p. 236). ${ }^{22}$ Therefore it is also understandable why Hadrian II stepped out the town to meet the so called Salonica brothers which was followed by honouring the mortal remains of St. Clement (V. Con.-Cyr. 9: p. 130; Tachiaos 2002: pp. 213-214).

18 It was put into effect by the Pope's letter called Industriae tuae (June 880; I. tuae: pp. 161-173).

19 The full designation in Latin was mainly Sanctae Dei ecclesiae res publica Romanorum (Krautheimer 2000: p. 108). For further information on the Papal republic, see also Noble (1991).

20 It seems that the life of the city started to be concentrated on some areas within the Aurelian walls. During the 9th century Rome might have had a population of about 35,000 that would remain for most of the Middle Ages (Baldovin 1987: p. 117).

21 Under Pope John IV (640-642) and Theodore I (642-649).

22 Later on, Hadrian I (772-795) had to impose a ban on the export of martyrs and saints' relics abroad (Costambeys \& Leyser 2007: p. 274). 
Pope Hadrian II might have ridden a horse during his first meeting with Constantine and Methodius outside the city of Rome. First, my hypothesis is based on an account in the Vita Hadriani II. (The Life of Hadrian II; V. Had. II, Lib. Pont. 108: pp. 259-294). There is one passage describing supposed visions of clergymen and devout laymen even before Hadrian II was elected as the Pope. He was supposed to have ridden a horse on the way in the manner of Pope Nicholas I (858-867). “..., and many people saw him (the later Hadrian II) with the papal pallium riding a horse that saint Pope Nicholas used to ride to St. Peter's Basilica when he returned to the city and entered his palace ${ }^{23}$ with honourable persons that preceded him and the rest of the crowd walked behind him in the procession." (V. Had. II, Lib. Pont. 108, 5: p. 261).

Similarly, the Popes were mounted on horses and conducted themselves during the stational liturgy of Easter Week that is described in the Ordo Romanus Primus. ${ }^{24}$ I cannot deny that it could probably have happened during the other stational liturgies in Rome ${ }^{25}$ throughout the rest of the year as well. To make the picture complete I should note that Pope Stephen II (752-757) participated in a short procession of the penitential character on the Assumption of Mary ( $15^{\text {th }}$ of August) when he and other attendees walked barefoot to the Basilica of St. Mary Major (Baldovin 1987: p. 163; V. Step. II, Lib. Pont. 94, 11: p. 57). On the Assumption of Mary in 847 Pontiff Leo IV (847-855) also led, on foot, a procession of the clergy and people to expel a basilisk from caves nearby the Basilica of St. Lucy the martyr (V. Leo. IV, Lib. Pont. 105, 18, 19: pp. 118, 119).

The last Roman version of the Ordo Romanus Primus, "handbook" for public worship in churches exercised by papal administration during Easter Week in Rome, can be dated to the last quarter of the $8^{\text {th }}$ century, ${ }^{26}$ i.e. before it was several times changed or modified north of the Alps from the last quarter of the $8^{\text {th }}$ century to the $10^{\text {th }}$ century (Noble 2001: p. 85; Romano 2007a: pp. 45, 54-55). ${ }^{27}$ It can be said that the Pope's pro-

23 It was the Lateran palace (Noble 2001: p. 53).

24 In my article I use the reconstruction of the Latin text dated to the middle of the 8th century and its translation that both were made by John F. Romano and published in print as well as online (OR I ver. 2012: pp. 1-8; FRO: pp. 1-8; OR I ver. 2014: pp. 229-248). As an example of the older compilation and translation of the studied source see for instance: OR I ver. 1905: pp. 116-149.

25 About the year 800 stational liturgies are marked by more than 100 stations (concretely 102) in seven regions of Rome which were in service on a particular occasion throughout the year (Noble 2001: pp. 84-85). John F. Baldovin (1987: pp. 35-37) precisely defined the late antique and early medieval Christian stational liturgy (from the early 4th century to the end of the 10th century) as “... a service of worship at a designated church, shrine, or public place in or near a city or town, on a designated feast, fast, or commemoration, which is presided over by the bishop or his representative and intended as the local church's main liturgical celebration of the day." Mark Humphries (2007: p. 53, footnote 158) assumed that the origins of this liturgy might go back to the 4th-5th centuries on the basis of the layout and planning of the fifth-century churches in Rome. This lasted approximately until the early fourteenth century (Romano 2014: p. 251).

26 There is no liturgical guide for Christian public worship before the 7th century at all. The Ordo Romanus Primus was written in the late 7th century (Pierce \& Romano 2011: p. 16; Romano 2007a: pp. 54-55).

27 Mass or the Eucharistic Liturgy of papal Rome during the discussed period of the 9th century was certainly different from that in the previous centuries. Today, it is not possible to study this fact satisfactorily in primary literary sources. Despite this statement there is some scarce information which can broaden our knowledge about the 9th century papal liturgy. A missal, a liturgical book containing every part and 
cession within the stational liturgy of Easter Week started in the Lateran palace. At dawn the lowest ranked clergymen (acolyti in Latin) of the third Roman quarter and members of each city quarter council (defensores in Latin) gathered and preceded the Pope on foot to each church of this stational liturgy (OR I ver. 2014 7: p. 230). ${ }^{28}$ The pontiff himself rode a horse and beside him, at both sides, grooms walked on foot in case a pontiff would have tripped up. Before the Pope, deacons of the city regions, the primicerius of the notaries and two regional notaries as well as subdeacons ${ }^{29}$ rode horses in two separate groups and kept a distance from him (OR I ver. 2014 8-9: pp. 230-231). Behind the Pope his vicedominus, vesterarius, nomincolator, and sacellarius (OR I ver. 2014 10: p. 231) rode horses. In this procession many liturgical items were borne ${ }^{30}$ and upon the procession's arrival at a church's altar ${ }^{31}$ the acolytes of seven city regions and the subdeacon with an incense burner preceded the Pope (OR I ver. 2014 46: p. 237). ${ }^{32}$ Several of the above mentioned liturgical items, namely crosses, candles (but likely without candlesticks), and incense burners were supposedly carried by the welcomers to Constantine and Methodius' arrival in Rome too, as it is stated above (Žit. Kon. XVII: p. 90; B. Klim. III, 9: p. 182; Usp. Kir.: p. 224).

There is also an account in Ordo Romanus Primus of the pontiff's vestments, including the pallium, which he should have put on with help from his entourage before Mass of Easter Week even started. ${ }^{33}$ Prior to Mass the evangeliary should have been placed on

prayer of Mass, started to appear right in the 9th century. In the 9th century Ordines Missarum commenced to contain apologies, a priest's private prayers purifying himself at the beginning of Mass, at the foot of an altar, at the offertory and Communion (Pierce \& Romano 2011: pp. 17, 20). Finally, in the 11th century Frankish influences on the Roman liturgy stood behind the emergence of the new papal liturgy for Rome based on the Rheinish Ordo Missae that the Popes started to spread to other regions of Europe in line with their interests (Doig 2009: p. 125; Pierce \& Romano 2011: p. 23; Romano 2007a: p. 72).

28 This liturgy was held at the Basilica of St. Mary Major on Easter Sunday, Basilica of St. Peter on Easter Monday, Basilica of St. Paul outside the Walls on Easter Tuesday, Basilica of St. Lawrence outside the Walls on Easter Wednesday, Basilica of the Holy Apostles on Easter Thursday, Basilica of St. Mary of the Martyrs on Easter Friday and at the Basilica of the Saviour on Easter Saturday (Baldovin 1987: p. 156; Romano 2007b: table 4.3, fig. 4.3).

29 Subdeacons used to carry the golden cross (usually used in the litanies) that was decorated with jacinths since Leo III (795-816) and with silver and unspecified jewels since Leo IV (V. Leo. III, Lib. Pont. 98, 25: p. 192; V. Leo. IV, Lib. Pont. 105, 28: p. 122; Goodson 2010: p. 16). According to the Life of Pontiff Leo IV they (probably one of them) directly bore this cross in their hands before the Pope's horse. It is not clear if they held the cross with both hands and walked or they held the cross with one hand or even with both hands and rode horse simultaneously. Maybe, since some unspecified time subdeacons (or some of them) had already started to walk before the Pope during the stational liturgy of Easter Week.

30 Those items consist of the liturgical vessels and tools, liturgical books, holy chrism, evangeliary, crosses or golden and silver candelabra (Noble 2001: pp. 85-86; OR I ver. 2014 11, 19-22: pp. 231-233).

31 In front of a church the Pope dismounted and having entered a church he went to the secretarium where he sat in his seat until his clothes were changed (OR I ver. 2014 29: p. 234).

32 Seven candelabra preceding the Pope in a stational church represented the seven quarters or regions of Rome which were visited during seven days by the procession (Noble 2001: pp. 84-86).

33 The regional subdeacons took all necessary vestments to put on the Pope according to their order: “... one the alb (linea in Latin), another a belt (cingulum in Latin), and another the anagolaium, that is the amice, another the linen dalmatic (linea dalmatica in Latin), and another the large dalmatic (maior dalmatica in Latin), and another the chasuble (planeta in Latin) and thus in order they clothe the Pope." (OR I ver. 
the altar by the hands of the second subdeacon (subdeaconus sequens in Latin; OR I ver. 2014 31: p. 234). The Long Life of St. Clement of Ohrid (B. Klim. III, 9: pp. 182, 183) informs us that the Slavonic liturgical books could have been treated in the same manner ${ }^{34}$ at the Basilica of St. Mary Major on the first day of the Slavonic liturgy celebration. I also know from the Life of Constantine the Philosopher that they were blessed by Pope Hadrian II, placed in the aforementioned basilica and the liturgy was chanted over them, as I have already stated above (Žit. Kon. XVII: p. 90). Following the Life of Methodius, the Archbishop of Moravia, the Pontiff himself ${ }^{35}$ laid the Slavonic evangeliary on the altar of the Basilica of St. Peter (Žit. Mef. VI: p. 126) where the Slavonic liturgy was also chanted.

As previously mentioned, Constantine and Methodius paid a visit to the Basilicas of St. Mary Major, St. Peter and Paul outside the Walls and the Chapels of St. Petronilla and St. Andrew during the three days of the Slavonic liturgy celebration. After ConstantineCyril's death his body was buried in the Church of St. Clement. These churches connected with martyr saints had special symbolic meanings for the Popes as well as the Salonica brothers. St. Peter, the Prince of the Apostles, and St. Paul, the Apostle of the Gentiles, who were martyred in Rome in the 60 s of the $1^{\text {st }}$ century AD became the patron saints of Rome (Francia 1975: p. 324) ${ }^{36}$ and their spiritual apostolic brotherhood (concordia apostolorum in Latin) became a well-liked emblem and model for the Roman Church (Sághy 2011: p. 10). As a matter of fact Great Moravia and the future Methodius' diocese in Pannonia and Moravia belonged to the Roman Patriarchate (Cibulka 1965: p. 321) and therefore to the Popes, successors of St. Peter. When Methodius was brought to trial in Eastern Francia (probably after 870) the Bavarian bishops accused him of teaching in their territory (Steinhübel 2014: p. 232). But he answered that this territory belonged to St. Peter (Žit. Mef. IX: p. 131). I take the view that the Chapel of St. Petronilla could also have represented the Frankish presence in Rome and the Church of St. Andrew along with the Basilica of St. Paul outside the Walls the Byzantine presence in Rome. St. Petronilla was supposedly the daughter of St. Peter and became a patron saint of the Frankish royal family as well. ${ }^{37}$ Then St. Andrew was one of the Constantinopolitan patron saints ${ }^{38}$

2014 34: p. 235). Eventually, one chosen deacon or subdeacon "... takes the pallium from the hand of the second subdeacon, and he drapes [it] over the Pope and fastens it with a pin (acus in Latin) behind and in front of the chasuble and on his left shoulder and kisses the lord, ..." (OR I ver. 2014 36: p. 235).

34 But the second subdeacon is not mentioned here.

35 In the primary literary source the name of Pope Nicolaus (I) is present, but in fact it concerns Pope Hadrian II.

36 In Late Antiquity the twin Christian apostles, Sts. Peter and Paul, were substituted for the former founders of Rome, Romulus and Remus, and gentile gods protecting Rome, Castor and Pollux (Sághy 2011: p. $10)$.

37 Pope Paul I brought the mortal remains of St. Petronilla to the mausoleum located beside the Basilica of St. Peter. The same Pope became godfather to Gisela, the daughter of the Frankish king Pippin III, in 757. After the baptism he placed her baptismal shawl in the interior of the chapel. Since then the Frankish kings were regarded as the foster-sons of St. Peter (Alchermes 1995: p. 5, fig. 2; Goodson 2010: pp. 27, 183-184, 215; Vavřínek 2013: p. 166).

38 A church devoted to St. Andrew might be perceived as an attempt to transfer his veneration to Rome. František Grivec claimed that this church might be identified with the Church of St. Gregory the Great on Mount Celio (quoted from Grotz 1970: p. 167, footnote 59). Although it was formerly the natal home of 
and St. Paul brought the Christian religion to Thessaloniki, to the birthplace of Constantine and Methodius (Tachiaos 2002: p. 214). The final funeral of Cyril took place in the Church of St. Clement because Methodius himself requested Hadrian II to place Cyril's body in this church (V. Con.-Cyr. 12: p. 112; Žit. Kon. XVIII: p. 94). Methodius also told the Pope that it was the aforementioned saint and the fourth Pope. "... whose body he (Constantine-Cyril) had found with a lot of effort and zeal and brought there (to Rome)" V. Con.-Cyr. 12: p. 112.

\section{II.2 On architecture}

Pope Leo III still kept his throne at the Lateran palace (called patriarchum or palatium in the Liber Pontificalis) in the beginning of the $9^{\text {th }}$ century. In addition to the Lateran palace, there was some kind of a papal residence built by this Pope in the Vatican complex (Noble 2001: p. 52). Therefore envoys or guests could visit several types of buildings within them which should be taken into consideration. The following ones should be considered: some of the reception and banqueting halls (triclinia, aulae, and atria in Latin), porticoes (porticus in Latin), esplanades, or meeting places called secretaria in Latin. Right here the Popes granted audiences to visitors, envoys, dignitaries, then they announced synodal resolutions, addressed the Romans, etc. (Noble 2001: pp. 53-54). The most representative ones were the aulae $^{39}$ or triclinia $^{40}$ whose designations could have been used for the same or similar looking buildings as well. In the Byzantine Empire, I would continuously trace the triclinia tradition back to the Late Roman architecture, whereas in the western part of the former Roman Empire it turned up again in the

Pope Gregory I (the Great; 590-604), this Pope transformed it into the Monastery of St. Andrew between 575 and 581 (Krautheimer 1937: p. 317). During the reign of the Pontiff Gregory II (715-731) the oratory dedicated to St. Gregory the Great already existed here. The Monastery of St. Andrew and the Oratory of St. Gregory the Great could have still been there during Constantine and Methodius' visit of Rome. Therefore they most likely visited the Chapel of St. Andrew beside St. Peter's Basilica (Cibulka 1964: pp. 16-17; Vavřínek 2013: p. 166). Its construction was commissioned by Pope Symmachus (498-518) in the former mausoleum situated beside St. Peter's Basilica. Veneration to St. Andrew in Rome as well as in Constantinople was associated with veneration to St. Thomas. Relics of both saints were placed in the so called Apostoleion (The Shrine of the Apostles) in Constantinople whose building was ordered by Constantine and finished in 336. In the Roman Chapel of St. Andrew a main altar was installed in the central niche and dedicated to St. Andrew and one of the lateral altars was dedicated to St. Thomas (Alchermes 1995: p. 5, fig. 2; Goodson 2010: pp. 183-184).

39 In Late Antiquity it was usually a large hall in palatium or villa used for amusement or audiences (Ulrich \& Quenemoen 2014: p. 482).

40 In Antiquity the Latin word triclinium originally designated the Roman dining room placed around the lateral and rear walls of a room. The triconch arrangement of triclinia was widely adopted during the Tetrarchy due to the increasing significance of a central space for entertainment during reclining banquets or dinners. This space could be easily seen from the dining areas or apses (Ulrich \& Quenemoen 2014: p. 499; Zarmakoupi 2014: p. 377). The reclining banquets of the 3rd-4th centuries were generally held in the so called stibadium style. That means that boarders were arranged in the form of the Latin letter C or Greek letter sigma (Smith 2012: p. 27). 
$8^{\text {th }}$ century ${ }^{41}$ and right in Rome and then in the Frankish Empire (Goodson 2010: p. 22; Lavin 1962: p. 12). They were obvious signs of a ruler's sovereignty and prestige and his connection with the Roman Empire tradition (Lavin 1962: p. 14). Representative triclinia within monarchic palaces were often fitted with more than three apses.

There would have been at least four triclinia at the Lateran palace in operation during the $9^{\text {th }}$ century and another two were very likely there as well. ${ }^{42}$ Pope Leo III built two triclinia. The larger one (V. Leo. III, Lib. Pont. 98, 39: pp. 197-198; Goodson 2010: p. 22; Luchterhandt 2006: Abb. 15, 19-21) ${ }^{43}$ was fitted with eleven apses ${ }^{44}$ (Aula Concilii) and the smaller one (V. Leo. III, Lib. Pont. 98, 10: pp. 183-184; Luchterhandt 2006: Abb. 6, 9-10 $)^{45}$ with five apses was even decorated with a mosaic on the central apse with symbolic motifs. At both sides of the apse (belonging to the smaller triclinium of Leo III) there were two scenes depicting the symbolic appointment to office - from the deputies of the heavens to the rulers on their knees. On the left side Jesus Christ is handing over keys to Pope Sylvester (314-335) or to St. Peter and a lance with a banner to Constantine the Great (306-337). On the right side St. Peter is giving a pallium to Pope Leo III and a lance with a banner to Charlemagne (768-814; Collins 2009: p. 149; Drake 2014: pp. 225-226; Krautheimer 2000: p. 115; Lavin 1962: p. 13; Goodson 2010: pp. 20-22, fig. 6; Noble 1991: pp. 323-324; Noble 2001: pp. 68-69; Nees 2002: pp. 189-190). The meaning of these scenes most likely expresses that the Roman Church had ever appointed its protector itself and that the sacred and profane power came from Rome (Drake 2014: p. 227; Walter 1993: p. VIIa/176). Guests or visitors of this triclinium likely came from the vestibule to the pre-aula area by stairs and having been summoned by nomenculatores they entered the aula through the colonnade. ${ }^{46}$ During festive entries papal singers (schola cantorum in Latin) went ahead of the clergy, judges, palace clerks and courtiers, and Roman aristocracy (Luchterhandt 2006: p. 184).

During the course of the $9^{\text {th }}$ century, papal splendour was on the decline and there were also tendencies for decentralisation of the papal power and ceremonies in Rome. Since circa 810 the Popes had cut spending on donations for Roman churches. For

41 Triclinia had ceased to be built in the Latin West or Western part of Europe as of the end of the 5 th century (Lavin 1962: p. 13).

42 As for the Lateran palace, the first triclinium was built by Pope Zachary (741-752), the other two were constructed by Pope Leo III and the last was set up by Pope Gregory IV (827-844; Noble 2001: pp. 52, 68). Leo III's project of the triclinia construction was probably underway at the same time as Charlemagne's palace at Aachen (Goodson 2010: p. 22). While Pontiff Leo IV commissioned the construction of a dining room and marble throne there, Nicholas I added to the Lateran palace a splendid house of some kind (Noble 2001: p. 52).

43 According to Richard Krautheimer (2000: pp. 121-122) it was 68 metres long and probably set up shortly after 800 .

44 The flank apses could have been fitted with tables and dining divans (accubita in Latin; Krautheimer 2000: p. 122).

45 Although the triclinium in Aachen was almost twice the size of the smaller triclinium of Pope Leo III, it lacked a lot of entrances and antechambers (Luchterhandt 2006: pp. 179, 180). Richard Krautheimer (2000: p. 115, fig. 88-90) tried to date this building from 798 or before April 799.

46 Manfred Luchterhandt's (2006: pp. 182, 182 footnote 32) assumption is based on the account regarding the layout of the Basilica Theodori within the Lateran Palace where the Church council was held in 745. 
instance, that meant that they provided these churches with less gold and purple fabric and with more silver and other cheaper items (Luchterhandt 2006: p. 200). Pontiff Stephen IV (816-817) and Paschal I (817-824) moved their residences from the Lateran palace to the Esquiline Hill, nearby two great churches - the Basilica of St. Mary Major and the Church of St. Praxedes the martyr. The trend towards private palaces alongside private churches for papal ceremonies could also be noticed during the pontificates of the next noble popes (Luchterhandt 2006: pp. 200-201). As it was stated above, Pope Gregory IV built a new triclinium (V. Greg. IV, Lib. Pont. 103, 15: p. 57) in the Lateran palace, but the triclinium of Leo III (one of his two ${ }^{47}$ was likely left during his time as well as during the reign of Pope Sergius II (844-847). ${ }^{48}$ Later on, Leo IV, once again, renewed this triclinium along with the whole palace and ceremonies within (V. Leo. IV, Lib. Pont. 105, 16: p. 117; Krautheimer 2000: p. 121; Luchterhandt 2006: pp. 200-201). In the end there were two probable triclinia built by Pope Leo IV himself and Nicholas I as well, as I have written above.

The Salonica brothers were probably given an audience with the Pope in the interiors or exteriors of the discussed complexes. Pope Hadrian II himself allegedly demonstrated his modesty and humbleness to the Greek and other monks during a banquet on Friday after the third Sunday before Lent (the $20^{\text {th }}$ of February) in 868 . It could have happened right in one of the aforementioned triclinia because he even reclined and dined with the monks there. ${ }^{49}$ We cannot exclude the possibility that Constantine and Methodius could have attended this banquet (Davis 1995: p. 267, footnote 42; Dvornik 1970: p. 138; Obolensky 1988: p. 10), but the banquet most likely referred to the followers or supporters of Rome-inclined Patriarch Ignatios (847-858, 867-877; Davis 1995: p. 266, footnote 40, p. 267).

The Liber Pontificalis also contains two examples of an audience with diplomats during the reign of Pope Hadrian II. Upon the arrival of Bishop Formosus of Porto and Bishop Paul of Populonia from their Bulgarian mission in Rome in 867 a meeting was arranged between Pope Hadrian II and the envoy of Bulgarian prince Boris-Michael (852-889), Peter, who came to Rome with both aforementioned bishops (Davis 1995: p. 289, footnote 133)..$^{50}$ "This envoy presented, with royal gifts, a royal letter as well, which earnestly begged the supreme prelate either to send back Marinus, the deacon whom he knew well, as consecrated archbishop, or to send the Bulgarians one of the cardinals of their choice, ...” (V. Had. II, Lib. Pont. 108, 61: p. 289). The next meeting might have been held in 868/869 between Hadrian II and Metropolitan John of Sylaeum (in Pamphylia),

47 Most likely the larger one (Krautheimer 2000: p. 121).

48 They had never held banquets there (V. Leo. IV, Lib. Pont. 105, 16: p. 117).

49 "In humility he personally poured water over the hands of them all, he set the meal, he served the cups, and, to make them more disposed to take part in the luncheon, he did what he knew no Pontiff before himself had done: he reclined with them, joining in with them in praising God with hymns and spiritual chants, (going through) the whole vast company of them there as they kept up a constant chorus (of praise)." (V. Had. II, Lib. Pont. 108, 16: p. 267).

50 It was the second embassy that Boris-Michael sent to the Roman Pope whose members asked Hadrian II, in vain, to appoint an archbishop or cardinal to Bulgaria (Todorov 2010: pp. 183, 184). 
the envoy of the Byzantine Emperor Basil I (867-886). ${ }^{51}$ The meeting place was the Basilica of St. Mary Major. According to the biographer of Pope Hadrian II this particular meeting place inside the basilica was the so called secretarium (V. Had. II, Lib. Pont. 108, 25: p. 272). ${ }^{52}$ "This holy Pope Hadrian as he sat with the bishops and the dignitaries in the secretarium of St. Mary Major, according to the custom of the holy apostolic see, and they presented gifts and letters." (V. Had. II, Lib. Pont. 108, 25: p. 272). Perhaps in this part of the basilica also Constantine, Methodius and their entourage might have been received by the Pope before, after, or aside from the liturgy.

In the $9^{\text {th }}$ century, the Popes also intended to improve their defence of the papal and especially Rome's territory against Arab raiders. The Salonica brothers could have seen, during their visit to the Vatican area, the walls of the city of Pope Leo IV as well. Leo IV commenced building a fortification around St. Peter's Basilica and its vicinity in 847 after a serious Arab raid in 846, when, besides this great church, the Basilica of St. Paul outside the Walls was pillaged too. This fortified suburb (finished in 853) was known as Civitas Leonina, the Leonine City (Baldovin 1987: p. 117; Collins 2009: pp. 155-156; Costambeys \& Leyser 2007: p. 263; Gantner 2012: pp. 406-407; Krautheimer 2000: p. 119). John VIII later enclosed the environs of St. Paul's Basilica with a wall in the 880s and since then the whole suburb became known as Johannipolis (Francia 1975: p. 324; Gregorovius 1895: pp. 186-187; Krautheimer 2000: pp. 119-120). If Methodius himself had hypothetically visited St. Paul outside the Walls in 879/880, he would have seen the walls of Pope John VIII's city under construction. Constantine and Methodius might have got to the Basilicas of St. Peter and St. Paul outside the Walls in 867/868 through the porticoes. The portico, which led to St. Paul's Basilica, protruded from the Aurelian walls right to this sacred church. ${ }^{53}$

\section{Conclusion}

All in all, the similar patterns of ceremonies and processions of the Easter Week liturgy or other stational liturgies might have been observed in the churches and streets of Rome during the presentation of the Slavonic liturgy by the Salonica brothers in 867/868. The related procession stopped at the following stations: the Basilicas of St. Mary Major and St. Peter (on the first day), then in the Chapels of St. Petronilla (on the second day) and St. Andrew (on the third day) and finally at the Basilica of St. Paul outside the Walls (at the third-day night).

51 The meeting forewent the council in St. Peter's Basilica that was held due to condemnation of Patriarch Photios' synod in Constantinople in 867 (Davis 1995: p. 271, footnote 66, p. 272, footnote 67).

52 It might have been a vestry where preparation for Mass took place and also it could have been a place where the clergy received guests during formal meetings, then a private chapel, and finally a place for synods (Davis 1995: p. 316; Romano 2007b: pp. 237, 239-240, fig. 4.2).

53 The aforementioned porticoes as well as the portico to the Basilica of St. Lawrence outside the Walls (which came out from the Aurelian walls too) were most likely constructed in the late 4th century. All of these porticoes were reconstructed in the late 8th century by Pontiff Hadrian I (V. Had. I, Lib. Pont. 97, 72-74: pp. 159-161; Dey 2014: pp. 72-73). 
It is obvious that Constantine and Methodius had departed from the city within the Aurelian walls (that was intra muros in Latin) during their procession in $867 / 868$, because the Basilica of St. Mary Major is located there. Then they moved through a portico to Civitas Leoniana where they visited the Basilica of St. Peter, the Chapel of St. Petronilla, and on the last day the Chapel of St. Andrew as well. The same day, but at night, they had to cross the city within the Aurelian walls and they most likely reached the Basilica of St. Paul, which stood behind the walls, through a portico. In 879/880 Methodius could have seen the walls of Johannipolis which were being created around the suburb where St. Paul's Basilica have stood.

The Popes evidently granted audiences to Constantine and Methodius in the most important sites of the Vatican complex, Lateran palace or in some great churches as the Basilica of St. Mary Major. The aulae, triclinia, atria, porticus and secretaria mainly belonged to sites within the complexes mentioned above. The Popes particularly received officers, visitors, addressed Romans and proclaimed synod resolutions here.

\section{Bibliography}

\section{Abbreviations of primary sources}

\begin{tabular}{|c|c|}
\hline B. Klim. & 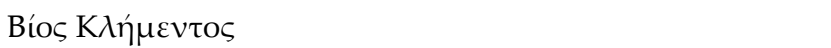 \\
\hline I. tuae & Industriae tuae \\
\hline Leg. sanct. & Legenda sanctorum Cyrilli et Metudii patronorum Moravie \\
\hline Lib. Pont. & Liber Pontificalis \\
\hline OR I ver. 1905 & Ordo Romanus Primus (version of the year 1905) \\
\hline OR I ver. 2012 & Ordo Romanus Primus (version of the year 2012) \\
\hline OR I ver. 2014 & Ordo Romanus Primus (version of the year 2014) \\
\hline Poch. slovo & Pochvalnoje slovo Kirillu i Mefodiju \\
\hline FRO & The First Roman Ordo \\
\hline Usp. Kir. & Uspenije Kirilla \\
\hline V. Con.-Cyr. & Vita Constantini-Cyrilli cum translatione s. Clementis \\
\hline V. Greg. IV & Vita Gregorii IV \\
\hline V. Had. I & Vita Hadriani I \\
\hline V. Had. II & Vita Hadriani II \\
\hline V. Leo. III & Vita Leonis III \\
\hline V. Leo. IV & Vita Leonis IV \\
\hline V. Step. II & Vita Stephani II \\
\hline Žit. Kon. & Žitije Konstantina Filosofa \\
\hline Žit. Mef. & Žitije Mefodija, archijepiskopa Moravıska \\
\hline Žit. Nau. II & Žitije Nauma II \\
\hline
\end{tabular}




\section{Primary sources}

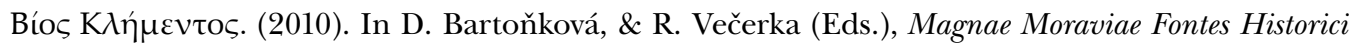
(Vol. II; pp. 179-209). Praha: Koniasch Latin Press.

Industriae tuae. (2011). In D. Bartoňková, \& R. Večerka (Eds.), Magnae Moraviae Fontes Historici (Vol. III; pp. 161-173). Praha: Koniasch Latin Press.

Legenda sanctorum Cyrilli et Metudii patronorum Moravie. (2010). In D. Bartoňková, \& R. Večerka (Eds.), Magnae Moraviae Fontes Historici (Vol. II; pp. 232-241). Praha: Koniasch Latin Press.

Ordo Romanus Primus. (1905). In E. G. C. F. Atchley (Ed.), Ordo Romanus Primus (pp. 116-149). London: De La More Press.

Ordo Romanus Primus. (2012). In J. F. Romano (Ed.), The First Roman Ordo (OR I): A new presentation of the Latin text [Retrieved 03.08.2016 from http://medievalliturgy.com/files/First_Roman_Ordo_Latin.pdf].

Ordo Romanus Primus. (2014). In J. F. Romano (Ed.), Liturgy and Society in Early Medieval Rome (pp. 229-248). Surrey - Burlington: Ashgate.

Pochvalnoje slovo Kirillu i Mefodiju. (2010). In D. Bartoňková, \& R. Večerka (Eds.), Magnae Moraviae Fontes Historici (Vol. II; pp. 145-152). Praha: Koniasch Latin Press.

The First Roman Ordo. (2012). In J. F. Romano (Ed.), The First Roman Ordo (OR I): A new translation [Retrieved 03.08.2016 from http://medievalliturgy.com/files/First_Roman_Ordo_English. pdf].

Uspenije Kirilla. (2010). In D. Bartoňková, \& R. Večerka (Eds.), Magnae Moraviae Fontes Historici (Vol. II; pp. 220-225). Praha: Koniasch Latin Press.

Vita Constantini-Cyrilli cum translatione s. Clementis. (2010). In D. Bartoňková, \& R. Večerka (Eds.), Magnae Moraviae Fontes Historici (Vol. II; pp. 103-113). Praha: Koniasch Latin Press.

Vita Gregorii IV, Liber Pontificalis 103. (1995). In R. Davis (Ed.), The Lives of the Ninth-Century Popes (Liber Pontificalis) (pp. 49-70). Liverpool: Liverpool University Press.

Vita Hadriani I, Liber Pontificalis 97. (1992). In R. Davis (Ed.), The Lives of the Eighth-Century Popes (Liber Pontificalis). The Ancient Biographies of Nine Popes from AD 715 to AD 817 (pp. 123-172). Liverpool: Liverpool University Press.

Vita Hadriani II, Liber Pontificalis 108. (1995). In R. Davis (Ed.), The Lives of the Ninth-Century Popes (Liber Pontificalis) (pp. 259-294). Liverpool: Liverpool University Press.

Vita Leonis III, Liber Pontificalis 98. (1992). In R. Davis (Ed.), The Lives of the Eighth-Century Popes (Liber Pontificalis). The Ancient Biographies of Nine Popes from AD 715 to AD 817 (pp. 179-230). Liverpool: Liverpool University Press.

Vita Leonis IV, Liber Pontificalis 105. (1995). In R. Davis (Ed.), The Lives of the Ninth-Century Popes (Liber Pontificalis) (pp. 111-160). Liverpool: Liverpool University Press.

Vita Stephani II, Liber Pontificalis 94. (1992). In R. Davis (Ed.), The Lives of the Eighth-Century Popes (Liber Pontificalis). The Ancient Biographies of Nine Popes from AD 715 to AD 817 (pp. 53-76). Liverpool: Liverpool University Press.

Žitije Konstantina Filosofa. (2010). In D. Bartoňková, \& R. Večerka (Eds.), Magnae Moraviae Fontes Historici (Vol. II; pp. 43-95). Praha: Koniasch Latin Press.

Žitije Nauma II. (2010). In D. Bartoňková, \& R. Večerka (Eds.), Magnae Moraviae Fontes Historici (Vol. II; pp. 226-228). Praha: Koniasch Latin Press. 
Žitije Mefodija, archijepiskopa Moravzska. (2010). In D. Bartoňková, \& R. Večerka (Eds.), Magnae Moraviae Fontes Historici (Vol. II; pp. 116-140). Praha: Koniasch Latin Press.

\section{Secondary sources}

Alchermes, J. D. (1995). Petrine Politics: Pope Symmachus and the Rotunda of St. Andrew at Old St. Peter's. The Catholic Historical Review, 81(1), 1-40.

Baldovin, J. F. (1987). The Urban Character of Christian Worship. The Origins, Development, and Meaning of Stational Liturgy (Orientalia Christiana Analecta, 228). Rome: Pont. Institutum Studiorum Orientalium.

Bartoňková, D., \& Večerka, R. (Eds.). (2010). Magnae Moraviae Fontes Historici (Vol. II). Praha: Koniasch Latin Press.

Bartoňková, D., \& Večerka, R. (Eds.). (2011). Magnae Moraviae Fontes Historici (Vol. III). Praha: Koniasch Latin Press.

Betti, M. (2014). The Making of Christian Moravia (858-882). Papal Power and Political Reality. Leiden: Brill.

Cibulka, J. (1964). Římské kostely, v nichž se na začátku r. 868 konala liturgie slovanská. Sbornik praci Filozofické fakulty brněnské university, F: ̌̌ada uměnovědná, 13(F8), 15-17.

Cibulka, J. (1965). Der Zeitpunkt der Ankunft der Brüder Konstantin-Cyrillus und Methodius in Mähren. Byzantinoslavica, XXVI, 318-364.

Collins, R. (2009). Keepers of the Keys of Heaven. A History of the Papacy. New York: Basic Books.

Costambeys, M., \& Leyser, C. (2007). To be the neighbour of St. Stephen: patronage, martyr cult, and Roman monasteries, c. 600-c. 900. In K. Cooper, \& J. Hillner (Eds.), Religion, Dynasty, and Patronage in Early Christian Rome, 300-900 (pp. 262-287). Cambridge: Cambridge University Press.

Davis, R. (Ed.). (1995). The Lives of the Ninth-Century Popes (Liber Pontificalis). Liverpool: Liverpool University Press.

Delikari, A. (2015). The Literary Work of the Cyrillo-Methodian Mission in Great Moravia and its Transmission around Ohrid during the $9^{\text {th }}$ and $10^{\text {th }}$ Centuries. Cyrillomethodianum, XX, 7-14.

Devos, P., \& Meyvaert, P. (1955). Trois énigmes cyrillo-méthodiennes de la «Légende Italique» résolues grace a un document inédit. Analecta Bollandiana, LXXIII, 375-461.

Dey, H. W. (2011). The Aurelian Wall and the Refashioning of Imperial Rome, AD 271-855. Cambridge: Cambridge University Press.

Dey, H. W. (2014). The Afterlife of the Roman City. Architecture and Ceremony in Late Antiquity and the Early Middle Ages. Cambridge: Cambridge Unviersity Press.

Doig, A. (2009). Liturgy and architecture: from the early church to the Middle Ages. Surrey: Ashgate.

Drake, H. A. (2014). Topographies of Power in Late Antiquity and Beyond. In C. Rapp, \& H. A. Drake (Eds.), The City in the Classical and Post-Classical World: Changing Contexts of Power and Identity (pp. 217-239). Cambridge: Cambridge University Press.

Dvornik, F. (1970). Byzantine Missions among the Slavs. SS. Constantine-Cyril and Methodius. New Brunswick - New Jersey: Rutgers University Press.

Francia, E. (1975). San Paolo fuori le Mura. In J. P. O’Neill (Ed.), The Vatican Spirit and Art of Christian Rome (pp. 324-331). New York: Metropolitan Museum of Art. 
Gantner, C. (2012). New Visions of Community in Ninth-Century Rome: The Impact of the Saracen Threat on the Papal World View. In W. Pohl, C. Gantner, \& R. Payne (Eds.), Visions of Community in the Post-Roman World. The West, Byzantium and the Islamic World, 300-1100 (pp. 403-421). Farnham - Burlington: Ashgate.

Geary, P. (2011). "Pull you Sons of Whores!" Linguistic Register and Reform in the Legend of St. Clement. In O. Gecser et al. (Eds.), Promoting the Saints. Cults and Their Contexts from Late Antiquity until the Early Modern Period. Essays in Honor of Gábor Klaniczay for His $60^{\text {th }}$ Birthday (pp. 41-49). Budapest - New York: Central European University Press.

Goodson, C. J. (2010). The Rome of Pope Paschal I. Papal power, urban renovation, church rebuilding and relic translation, 817-824. Cambridge: Cambridge University Press.

Gregorovius, F. (1895). History of the City of Rome in the Middle Ages (Vol. III; Transl. by A. Hamilton). London: George Bell \& Sons.

Grotz, H. (1970). Erbe wider Willen. Hadrian II. (867-872) und seine Zeit. Wien - Köln - Graz: Hermann Böhlaus Nachf.

Humphries, M. (2007). From emperor to pope? Ceremonial, space, and authority at Rome from Constantine to Gregory the Great. In K. Cooper, \& J. Hillner (Eds.), Religion, Dynasty and Patronage in Early Christian Rome, 300-900 (pp. 21-58). Cambridge: Cambridge University Press.

Ivanič, P., \& Lukáčová, M. (2014a). Journeys of St. Methodius within the years 860-881. Istorija. Journal of History, XLIX(1), 89-104.

Ivanič, P., \& Lukáčová, M. (2014b). Historicko-geografický kontext misií solúnskych bratov (Cesty sv. Konštantína-Cyrila a Metoda do roku 867). Konštantínove listy, 7, 2-13.

Ivanič, P., \& Lukáčová, M. (2015). Svätý Metod na misijných a diplomatických cestách (Historickogeografické súvislosti). Historický časopis, 63(4), 649-660.

Krautheimer, R. (1937). Corpus Basilicarum Christianarum Romae. Le basiliche crisiane antiche di Roma (Sec. IV-IX) (Vol. I). Roma: Pontifico Instituto di Archeologia Cristiana.

Krautheimer, R. (2000). Rome. Profile of a City, 312-1308. With a new foreword by Marvin Trachtenberg. Princeton: Princeton University Press.

Lavin, I. (1962). The house of the Lord: Aspects of the role of palace triclinia in the architecture of late Antiquity and the early Middle Ages. The Art Bulletin, 44, 1-27.

Löwe, H. (1983). Cyrill und Methodius zwischen Byzanz und Rom. In Gli Slavi occidentali e meridionali nell'alto Medioevo: 15-21 aprile 1982. Tomo Secondo (pp. 631-686). Spoleto: Presso la sede del centro.

Luchterhandt, M. (2006). Stolz und Vorurteil. Der Westen und die byzantinische Hofkultur im Frühmittelalter. In F. A. Bauer (Ed.), Visualisierungen von Herrschaft. Frühmittelalterliche Residenzen - Gestalt und Zeremoniell (pp. 171-211). Istanbul: Ege Yayınları.

Marinčák, Š. (2005). Slovanská liturgia - liturgické dedičstvo byzantskej misie z 9. storočia? Slavica Slovaca, 40(1), 34-62.

Marsina, R. (1985). Metodov boj (1 $1^{\text {st }}$ ed.). Bratislava: Obzor.

Marsina, R. (2012). Metodov boj ( $3^{\text {rd }}$ ed.). Bratislava: Vydavatel'stvo Spolku slovenských spisovatelov. Nees, L. (2002). Early Medieval Art. Oxford: Oxford University Press.

Noble, T. F. X. (1991). The Republic of St. Peter. The Birth of the Papal State, 680-825. Philadelphia: University of Pennsylvania Press.

Noble, T. F. X. (2001). Topography, celebration, and power: the making of a papal Rome in the 
eighth and ninth centuries. In M. de Jong, F. Theuws, \& C. van Rhijn (Eds.), Topographies of Power in the Early Middle Ages (pp. 45-91). Leiden: Brill.

Obolensky, D. (1988). Six Byzantine Portraits. Oxford: Oxford University Press.

Pentkovskij, А. М. (2014). Славянское богослужение в архиепископии святителя Мефодия. In J. Radić, \& V. Savić (Eds.), Свети Ћирило и Методије и словенско писано наслеђе 863-2013 (pp. 25-102). Beograd: Institut za srpski jezik SANU.

Pierce, J. M., \& Romano, J. F. (2011). The Ordo Missae of the Roman Rite. Historical Background. In E. Foley (Ed.), A Commentary on the Order of Mass of the Roman Missal: A New English Translation (pp. 3-33). Collegeville (MN): The Liturgical Press.

Romano, J. F. (2007a). The Fates of Liturgies: Towards a History of the First Roman Ordo. Antiphon, 11(2), 43-77.

Romano, J. F. (2007b). Ritual and Society in Early Medieval Rome. PhD dissertation. Cambridge, MA: Harvard University.

Romano, J. F. (2009). Announcing the Station in Early-Medieval Rome: A New Interpretation of 'Statio' in OR I, 108. Archiv für Liturgiewissenschaft, 51, 345-351.

Romano, J. F. (2014). Liturgy and Society in Early Medieval Rome. Surrey - Burlington: Ashgate.

Sághy, M. (2011). Pope Damascus and the Beginnings of Roman Hagiography. In O. Gecser et al. (Eds.), Promoting the Saints. Cults and Their Contexts from Late Antiquity until the Early Modern Period. Essays in Honor of Gábor Klaniczay for His $60^{\text {th }}$ Birthday (pp. 1-15). Budapest - New York: Central European University Press.

Smith, D. E. (2012). The Greco-Roman Banquet as a Social Institution. In D. E. Smith, \& H. Taussig (Eds.), Meals in the Early Christian World. Social Formation, Experimentation, and Conflict at the Table (pp. 23-33). New York: Palgrave Macmillan.

Steinhübel, J. (2014). Methodius' conflict with the Bavarian bishops. In P. Kouřil et al., The Cyril and Methodius Mission and Europe. 1150 Years since the Arrival of the Thessaloniki Brothers in Great Moravia (pp. 228-233). Brno: The Institute of Archaeology of the Academy of Sciences of the Czech Republic.

Škoviera, A. (2007). Liturgia cyrilometodskej misie na Velkej Morave. In J. Michalov et al. (Eds.), Duchovné, intelektuálne a politické pozadie cyrilometodskej misie pred jej prichodom na Vel'kú Moravu (pp. 104-130). Nitra: Univerzita Konštantína Filozofa v Nitre.

Škoviera, A. (2013a). O cyrilo-metodských prameňoch a ich prekladoch do slovenčiny. In Slová Slovanov (pp. 142-151). Bratislava: Literárne informačné centrum.

Škoviera, A. (2013b). Stereotypy v interpretáciách textov o bohoslužobných jazykoch v cyrilo-metodských prameňoch. In E. Brtáňová (Ed.), Literárnohistorické kolokvium. I: Stredovek, II: Humanizmus a renesancia (pp. 11-31). Bratislava: Ústav slovenskej literatúry SAV.

Tachiaos, A.-E. N. (2002). Cyril and Methodius' Visit to Rome in 868: Was it Scheduled or Fortuitous? In P. Schreiner, \& O. Strakhov (Eds.), Chrysai Pylai. Zlataja Vrata. Essays presented to Ihor Ševčenko on his eightieth birthday by his colleagues and students (Palaeoslavica, 10/2; pp. 210-221). Cambridge, MA: Palaeoslavica.

Taft, R. F. (1992). The Byzantine Rite. A Short History. Collegeville: The Liturgical Press.

Todorov, B. A. (2010). Coercion and Reconciliation: The Roman Mission of AD 866/7 and the Internal Conflicts in Bulgaria. In T. Stepanov, \& G. Kazakov (Eds.), Medieval Christianitas. Different Regions, 'Faces', Approaches (pp. 181-202). Sofia: Voenno izdatelstvo Publishing House Ltd. 
Ulrich, R. B., \& Quenemoen, C. K. (Eds.). (2014). A Companion to Roman Architecture. Chichester: Wiley Blackwell.

Vavřínek, V. (2013). Cyril a Metoděj mezi Konstantinopoli a Řimem. Praha: Nakladatelství Vyšehrad. Walter, Ch. (1993). Papal political imagery in the medieval Lateran palace (VIIa). In Ch. Walter (Ed.), Prayer and Power in Byzantine and Papal Imagery (VIIa/155-VIIa/176). Aldershot: Variorum.

Zarmakoupi, M. (2014). Private Villas: Italy and the Provinces. In R. B. Ulrich, \& C. K. Quenemoen (Eds.), A Companion to Roman Architecture (pp. 363-380). Chichester: Wiley Blackwell.

Mgr. Martin Husár, PhD. / mhusar@ukf.sk

Institute for Research of Constantine and Methodius' Cultural Heritage

Constantine the Philosopher University in Nitra, Faculty of Arts

Trieda A. Hlinku 1, 94974 Nitra, Slovakia 